\title{
PSEUDOTUMOR TUBERKULOSIS HATI DIAGNOSIS MELALUI BIOPSI ASPIRASI JARUM HALUS
}

\author{
Poppy M Lintong
}

\author{
Bagian Patologi Anatomi Fakultas Kedokteran Universitas Sam Ratulangi Manado \\ Email:magda_plin@yahoo.com
}

\begin{abstract}
Nowadays, the role of Fine Needle Aspiration Biopsy (FNAB) in the evaluation of focal lesions in the liver, especially nodular hepatocellular carcinoma, is well developed. As one of the diagnostic tools, FNAB is very important in making a preoperative diagnosis to prevent unneeded hepatectomy. Although a CT scan or USG can detect a tubercular lesion in the abdominal cavity, this imaging is not always specific, and still needs microbiologic and histopathologic examinations for further confirmation. We reported a case of a 45-year-old female with a tumor in the right upper abdominal cavity. She had undergone a USG twice with two different results: the first one was a hepatoma, and the second one was a benign nodule of the liver. The AFP test was within normal limits $(2.6 \mathrm{mg} / \mathrm{ul})$. FNAB showed a tubercular granuloma consisting of epitheloid cell aggregations and Langhans datia cells, with a background of necrotic tissues, connective tissue fibrils, and normal hepatocytes. Localized tuberculosis as a clinical entity producing large nodules is exceedingly rare, even in endemic areas. These pseudotumors often resemble metastatic cancer, clinically and radiographically. By using FNAB we can detect liver tuberculosis that clinically manifests as a tumor.
\end{abstract}

Keywords: FNAB, liver tuberculosis, pseudotumor.

\begin{abstract}
Abstrak: Saat ini peranan biopsi aspirasi jarum halus dalam hal menilai kelainan-kelainan fokal pada hati sudah berkembang, terutama pada nodul karsinoma hepatoseluler. Biopsi aspirasi jarum halus pada hati sebagai salah satu sarana diagnostik sangat berguna untuk menegakkan diagnosis preoperatif sehingga dapat menghindari tindakan hepatektomi yang tidak perlu. Meskipun pemeriksaan computerized tomography scan (CT-scan) dan ultrasonography (USG) pada hati dapat mendeteksi lesi tuberkulosis dalam rongga perut, namun pencitraannya tidak selalu spesifik sehingga membutuhkan konfirmasi pemeriksaan mikrobiologi dan histopatologi. Dilaporkan kasus seorang wanita berusia 45 tahun dengan tumor pada perut kanan atas. Telah dilakukan dua kali pemeriksaan USG: yang pertama hasilnya suatu hepatoma dan yang kedua suatu nodul jinak pada hati. Pemeriksaan alpha-feto protein (AFP) dalam batas normal $(2,6$ $\mathrm{mg} / \mathrm{ul}$ ). Kemudian dilakukan pemeriksaan biopsi aspirasi jarum halus dengan hasil menunjukkan granuloma tuberkulosis dari agregat sel-sel epiteloid yang tersusun dalam granuloma dan sel-sel datia Langhans dengan latar belakang fokus-fokus nekrosis, fibril jaringan ikat serta sel-sel hati normal. Tuberkulosis terlokalisir pada hati yang secara klinik menimbulkan nodul besar, sangat jarang terjadi, sekalipun pada daerah endemik. Pseudotumor seperti ini sering menyerupai metastatik kanker secara klinik dan radiologik. Melalui pemeriksaan biopsi aspirasi jarum halus dapat dikonfirmasi suatu tuberkulosis hati yang klinisnya memberi manifestasi seperti tumor.
\end{abstract}

Kata kunci: biopsi aspirasi jarum halus, tuberkulosis hati, pseudotumor.

Dewasa ini untuk mendiagnosis lesi-lesi pada hati dan atau rongga perut sering digunakan computerized tomography scan (CT- scan) dan ultrasonography (USG). Padahal pencitraan yang diperoleh dari CT-scan dan USG tidak selalu spesifik, sehingga kita 
membutuhkan konfirmasi tambahan. Di antaranya dengan menggunakan biopsi aspirasi jarum halus (fine needle aspiration biopsy, FNAB). Konfirmasi tambahan ini merupakan keniscayaan, karena selain dapat memperoleh data yang lebih spesifik, juga bermanfaat untuk mencegah tindakan operatif yang tidak perlu.

Tulisan ini memaparkan laporan kasus seorang penderita dengan diagnosis klinis dan USG adalah hepatoma, tetapi dengan FNAB ternyata adalah suatu tuberkulosis hati.

\section{TINJAUAN PUSTAKA}

Granuloma hepatik sudah dilaporkan presentasinya $2-10 \%$ dari semua spesimen hati yang diperiksa. Beberapa penyebab granuloma sukar diketahui, namun terbanyak akibat infeksi. Para ahli klinik juga mengusulkan beberapa penyakit noninfeksi dalam melakukan diagnosis banding seperti sarkoidosis, primary billiary cirrhosis (PBC), reaksi obat, berylliosis, penyakit Hodgkin's, dan reaksi terhadap benda asing. ${ }^{1}$

Proses granulomatosis kadang-kadang memberikan manifestasi sebagai lesi hati multipel menyerupai abses atau metastasis. Penyebab utama adalah bakteri dan jamur; dan mikobakterium tuberkulosis merupakan penyebab paling banyak diseluruh dunia. Hampir semua kasus tuberkulosis pada hati berasal dari tuberkulosis milier. Sepertiga dari populasi global sudah terinfeksi dengan mikobakterium tuberkulosis. Faktor-faktor yang menimbulkan masalah medik secara global antara lain infeksi human immunodeficiency virus (HIV), penanganan kasus buruk dan kekambuhan, migran dan pengungsi, serta resistensi obat. Studi evaluasi peranan biopsi hati menunjukkan bahwa penderita dengan infeksi HIV, terbanyak disertai infeksi mikobakterium tuberkulosis, diikuti oleh histoplasmosis dan kriptokokosis. Kasus tuberkulosis hati pada penderita infeksi HIV (dan atau aquired immunodeficiency syndrome, AIDS) sudah dilaporkan juga oleh Issei K,dkk. ${ }^{1-4}$

Gejala dan tanda-tanda tuberkulosis hati sering asimptomatik, hepatomegali, nyeri perut kuadran kanan atas, dan demam. Asites dan ikterus jarang. Bilirubin dan transaminase meningkat tidak seimbang dengan alkaline phosphatase yang tinggi. Granuloma yang menyatu menimbulkan massa hepatik (tuberkuloma) dan limfadenopati periportal. Tuberkulosis terlokalisir pada hati yang secara klinik menimbulkan nodul besar sangat jarang terjadi sekalipun pada daerah endemik. Pseudotumor seperti ini secara klinik dan radiologik sering menyerupai metastatik kanker. Pemeriksaan basil tahan asam (BTA), termasuk sitologi empedu dan gambaran karakteristik sitohistologik dari granuloma kaseosa dapat direkomendasikan jika lesi-lesi hepatik dengan gejala yang sudah berlangsung lama tidak dapat dibuktikan keganasannya. Pada tuberkulosis hepatobilier dapat terbentuk nodul-nodul besar atau abses pada hati, sehingga disebut pseudotumor karena sering menyerupai kanker metastatik secara klinik dan radiologik. Manifestasi klinik seperti hepatomegali yang disertai demam dan penurunan berat badan juga mirip gejala keganasan. ${ }^{1,2,5}$

Morfologi granuloma dapat memberi nilai bermakna untuk diagnosis. ${ }^{1}$ Gambaran histopatologik tuberkulosis hati menunjukkan pola klasik tuberkulosis yang terdiri dari sel-sel epiteloid, sering disertai nekrosis kaseosa dan sel datia Langhans. Basil-basil tahan asam sering hanya sedikit atau tidak ada dengan pengecatan Ziehl-Neelsen. Pada kasus-kasus berat, terdapat tuberkel-tuberkel jenis soft, granuloma tidak matur dengan nekrosis fibrinoid sentral, tidak ada sel datia dan dan basil-basil tahan asam lebih banyak. Pada lesi-lesi yang lama dapat menunjukkan fibrosis, kalsifikasi, dan kadang-kadang degenerasi amiloid. Oleh karena sulit untuk mendeteksi mikobakterium dengan pewarnaan khusus Ziehl-Neelsen, maka pemeriksaan kultur dan polymerase chain reaction (PCR) lebih bermakna. Tehnik-tehnik spesifik lain mencakup mikroskop elektron, imunohistokimia, fase kontras mikroskopi, mikroradiografi, dan difraksi sinar $\mathrm{X}$ dapat juga membantu diagnosis. Penggunaan USG dan CTscan untuk mendeteksi tuberkulosis hati bentuk makronoduler sudah dilaporkan pada anak laki-laki usia lima tahun. Pada pemerik- 
saan sonografi suatu tuberkuloma dapat berupa massa hypoechoic atau massa kistik dengan atau tanpa septa, yang mana tidak spesifik. Namun deteksi massa kistik yang mengandung kalsifikasi atau suatu massa kalsifikasi dapat dicurigai sebagai abses tuberkulosis atau granuloma yang telah sembuh. ${ }^{1,3,6-8}$

Sarana diagnostik biopsi aspirasi jarum halus pada peradangan hati sangat terbatas terutama bilamana proses penyakitnya difus. Biopsi aspirasi jarum halus hanya dapat dilakukan jika lesi berbentuk nodul. Bahan biopsi aspirasi jarum halus pada tuberkulosis menunjukkan gambaran granuloma tipikal terdiri dari sel-sel histiosit epiteloid dengan latar belakang bercampur dengan bahan nekrosis kaseosa. Sel-sel datia Langhans dapat dijumpai diantara sel-sel radang kronik. Pewarnaan Ziehl-Neelsen sangat penting untuk melihat basil tahan asam pada hapusan dan blok sel. Beberapa laboratorium tersedia tehnik pemeriksaan PCR untuk mengidentifikasi basil-basil ini. Sampel dari aspirat dapat dikirim ke laboratorium untuk kultur dan uji sensitivitas. Diagnosis sempurna granuloma hepatik membutuhkan pemeriksaan histologik dari granuloma, dan potongan bertahap sangat membantu dan penting bilamana penyakit granulomatosa sudah dicurigai tetapi tidak ditemukan pada potongan awal. ${ }^{2,9-11}$

Sampai saat ini tuntunan biopsi aspirasi jarum halus sudah diterima sebagai prosedur yang aman untuk mendapatkan diagnosis jaringan dalam penanganan penderita dengan lesi fokal hati. Namun peranan biopsi aspirasi jarum halus untuk mengevaluasi lesi tersebut terutama karsinoma hepatoseluler juga masih terdapat kendala dalam diagnostik. Algoritma pendekatan secara umum diagnosis biopsi aspirasi jarum halus terhadap penderita dengan lesi-lesi fokal terdiri dari lima tahap yaitu: pertama menetapkan kelompok presentasi klinik; kedua melakukan pemeriksaan radiologik; ketiga biopsi aspirasi jarum halus untuk menetapkan penemuan sitohistologik; keempat tehnik tambahan atau penyokong terutama pewarnaan khusus, imunohistokimia; dan kelima korelasi klinikopatologik. $^{12}$

\section{LAPORAN KASUS}

Seorang wanita usia 45 tahun (pada tanggal 30 April 2009) datang ke tempat praktek dengan gejala rasa tidak enak pada daerah hipokondrika kanan. Pada pemeriksaan teraba tumor pada perut kanan atas. Empat belas bulan sebelumnya pada tanggal 23 Januari 2008 pada penderita telah dilakukan pemeriksaan USG, dan hasil diagnosisnya adalah hepatoma. Kemudian pada tanggal 14 Oktober 2008 dilakukan lagi pemeriksaan USG di laboratorium yang lain dan hasilnya menyimpulkan suatu hepatomegali dengan nodul jinak pada lobus kiri hati. Pada saat ini pemeriksaan darah: SGOT $72 \mathrm{mg} / \mathrm{dl}$, SGPT $50 \mathrm{mg} / \mathrm{dl}$, fosftase alkali $486 \mathrm{mg} / \mathrm{dl}$. Pemeriksaan AFP (alpha-feto protein) 2,6 mg/ul. Tanggal 20 Oktober 2008 pemeriksaan bilirubin total $1,37 \mathrm{mg} / \mathrm{dl}$. Pemeriksaan darah 30 April 2009 bleding time 4'30' dan clotting time 1'30'. Pada tanggal 1 Mei 2009 dilakukan FNAB pada nodul hepar bagian kiri. Hasil FNAB menunjukkan sediaan hapus terdiri atas agregat sel-sel epiteloid yang tersusun membentuk granuloma dan sel-sel datia Langhans; dengan latar belakang fokus-fokus nekrosis, fibril jaringan ikat, dan sel-sel hati normal berbentuk poligonal. (Gambar 1,2, dan 3). Diagnosis FNAB adalah radang granulomatik, pseudotumor tuberkulosis hati. Dari spesimen apusan FNAB dibuat pemeriksaan PCR namun hasilnya negatif. Penderita tidak mempunyai riwayat hepatitis, sirosis atau peminum alkohol.

\section{PEMBAHASAN}

Ultrasonografi saat ini menjadi salah satu tehnik pencitraan yang paling sering digunakan dalam praktik medik, dan banyak dipakai pada lesi-lesi rongga perut terutama organ hati. Pada kasus ini penderita sudah dua kali dilakukan pemeriksaan USG. Hasil yang pertama adalah hepatoma, dan yang kedua hepatomegali dengan nodul jinak. Hepatoma atau karsinoma hepatoseluler secara klinik jarang karakteristik, sering mempunyai latar belakang infeksi hepatitis kronik atau sirosis. Pada hepatoma, alfa- feto protein 

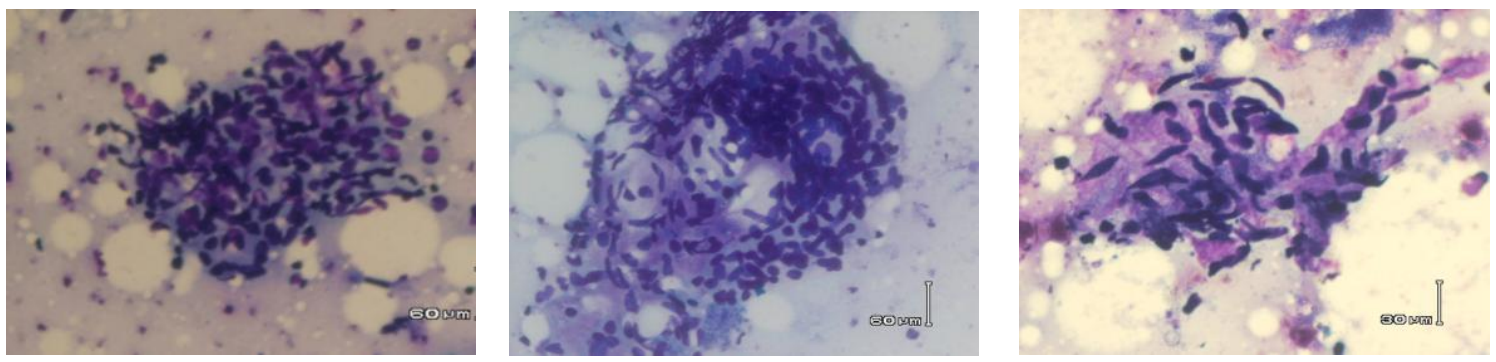

Gambar 1. Gambar mikroskopik granuloma tuberculosis, terdiri atas sel-sel epiteloid. Pada bagian paling kanan sel-sel epiteloid dengan latar belakang nekrosis.
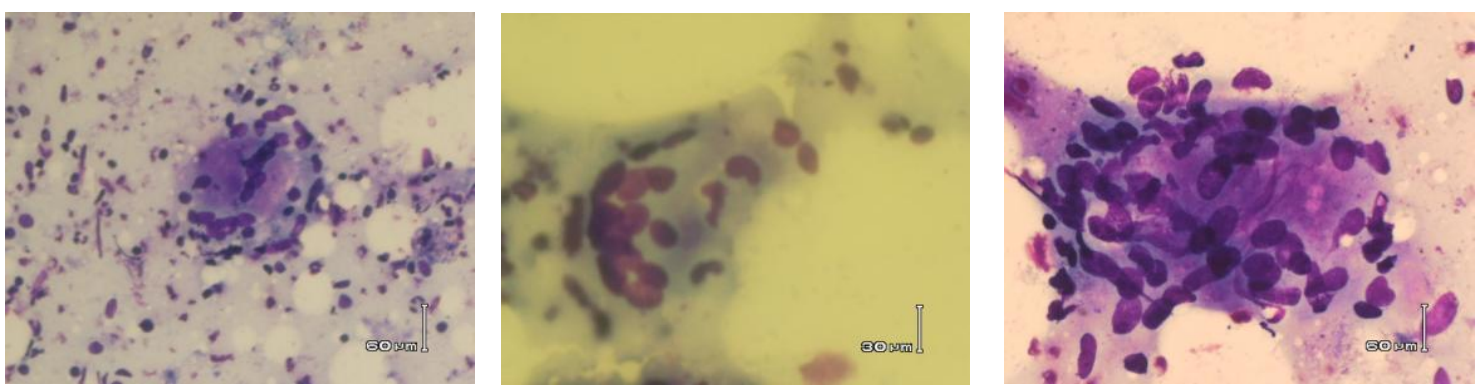

Gambar 2. Gambar mikroskopik sel-sel datia Langhans.
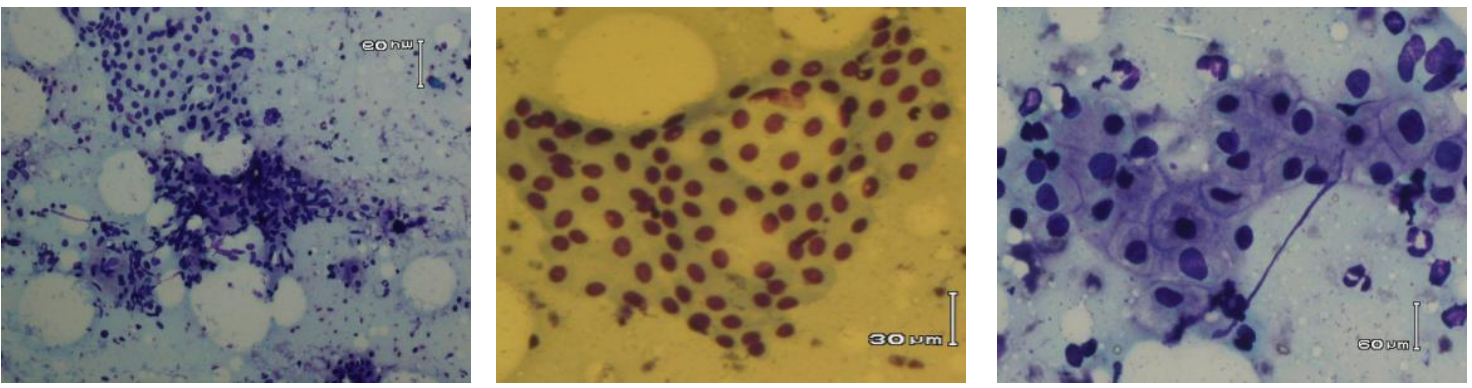

Gambar 3. Gambar mikroskopik sel-sel hati normal; sel-sel berbentuk poligonal dengan sitoplasma luas, umumnya membentuk cohesive sheets

(AFP) meningkat pada 50-75\% kasus. Dalam perjalanan penyakit hepatoma, sering berlangsung progresif sampai terjadi gangguan fungsi hati dan metastase ke organ lain. Neoplasma jinak pada hati, biasanya berasal dari sel-sel hati, disebut adenoma sel hati. Adenoma ini cenderung terjadi pada wanita dengan pemakaian kontrasepsi oral dan secara klinis sering keliru didiagnosis sebagai hepatoma. Pada kasus ini penderita tidak mempunyai riwayat hepatitis maupun sirosis, AFP dalam batas normal, sehingga suatu hepatoma dapat disingkirkan. Lebih jauh, sudah lebih dari setahun sebelum diagnosis biopsi aspirasi jarum halus ditegakkan, penderita tidak menunjukkan adanya tanda- tanda metastasis suatu tumor. ${ }^{8,13}$

Hasil pemeriksaan kimia darah pada kasus ini menunjukkan SGOT $72 \mathrm{mg} / \mathrm{dl}$, SGPT $50 \mathrm{mg} / \mathrm{dl}$, alkaline phosphatase 486 $\mathrm{mg} / \mathrm{dl}$, dan bilirubin total $1,37 \mathrm{mg} / \mathrm{dl}$. Data laboratorium ini menunjang diagnosis tuberkulosis secara klinis. Sesuai acuan pustaka disebutkan, bahwa tanda-tanda tuberkulosis hati jarang menunjukkan ikterus, dan peningkatan bilirubin serta transaminase tidak seimbang dengan alkaline phosphatase yang tinggi.

Tuberkulosis bentuk milier dan terlokalisir pada hati jarang terjadi, sehingga pada pemeriksaan USG dua kali tidak dicurigai sebagai tuberkulosis. Pemeriksaan USG pada 
tuberkulosis hati tidak spesifik. Pada penderita ini dilakukan pemeriksaan biopsi aspirasi jarum halus untuk mendapatkan gambaran sitohistologik. Hal ini sesuai dengan tahap-tahap pendekatan algoritma yang diterapkan pada penderita dengan lesi fokal pada hati. Hasil pemeriksaan biopsi aspirasi jarum halus menunjukkan gambaran granuloma tipikal (Gambar 1,2). Hal ini menyingkirkan dugaan klinis dan pemeriksaan USG sebagai hepatoma. Apalagi dalam sediaan apus bahan biopsi aspirasi jarum halus terlihat selsel hati normal yang berbentuk poligonal (Gambar 3). Tuberkulosis hati sangat jarang dijumpai. Bilamana granuloma tuberkulosis menyatu dapat menimbulkan massa hepatik (tuberkuloma) yang menyerupai tumor atau metastasis kanker sehingga disebut pseudotumor. Granuloma hepatik selain disebabkan oleh tuberkulosis dapat juga disebabkan oleh jamur, sehingga untuk menunjang diagnosis tuberkulosis perlu dilakukan pemeriksaan basil tahan asam dengan pengecatan Ziehl Neelsen. Sering sulit untuk mendeteksi mikobakterium tuberkulosis dengan pengecatan Ziehl Neelsen, maka kultur dan pemeriksaan PCR lebih bermakna. Pada pasien ini tidak sempat dilakukan pemeriksaan basil tahan asam, tetapi dari bahan apusan biopsi aspirasi jarum halus dibuat pemeriksaan PCR namun memberi hasil negatif. Hal ini sesuai dengan acuan pustaka yang menyatakan bahwa pola klasik tuberkulosis yang terdiri atas sel-sel epiteloid, nekrosis kaseosa dan sel datia Langhans, sering basil-basil tahan asam hanya sedikit atau tidak ada. ${ }^{1-3,5,8}$

Satu kasus tuberkulosis hepatobilier (pseudotumor tuberkulosis) sudah dilaporkan oleh Wee Aileen. Pada kasus ini diagnosis ditegakkan berdasarkan pemeriksaan biopsi aspirasi jarum halus dengan tuntunan CTscan, dan dari bahan biopsi aspirasi jarum halus telah dibuat pemeriksaan basil tahan asam berulang kali hasilnya juga negatip. Namun setelah dibuat pemeriksaan basil tahan asam dari bahan sitologi cairan empedu hasilnya positip, sehingga menunjang diagnosis pasti tuberkulosis. ${ }^{14}$

\section{KESIMPULAN}

Telah dilaporkan satu kasus pseudotumor tuberkulosis hati pada wanita usia 45 tahun yang memberi manifestasi klinik dan radiologik sebagai tumor.

Diagnosis pseudotumor tuberkulosis hati pada kasus ini ditegakkan melalui pemeriksaan biopsi aspirasi jarum halus yang menunjukkan adanya granuloma tipikal. Pemeriksaan PCR untuk basil mikobakterium tuberkulosis dari bahan biopsi aspirasi jarum halus hasilnya negatif. Walaupun mikobakterium tuberkulosis sebagai penyebab tuberkulosis hati tidak dapat dibuktikan melalui PCR, namun gambaran klinis dan diagnosis sitologik sangat menyokong diagnosis tuberkulosis hati.

Dalam penanganan kasus seperti ini perlu kerja sama ahli klinik, bedah, radiologi, dan patologi untuk menegakkan diagnosis pasti sehingga dapat diberikan pengobatan yang rasional dan hal ini dapat menghindari suatu tindakan pembedahan yang tidak perlu.

\section{DAFTAR PUSTAKA}

1. Laura LW, Kay W. Acute and chronic hepatitis. In: Surgical Pathology of the GI Tract, Liver, Biliary Tract, Pancreas. Robert D Odze, John R Goldblum, James W Crawford, editors. Philadelphia: Saunders Elsevier, 2004; p.799-800.

2. Aileen $\mathbf{W}$, Pichet $\mathbf{S}$. Fine needle aspiration cytology of the liver. Diagnostic algorithms. A Southeast Asian prespective. Bangkok: Year Book Publisher Co.Ltd, 2004; p.108-109, 159-161.

3. Alastair BD, Bernard PC, Ferrell LD. Mac Sween's pathology of the liver. $5^{\text {th }}$ ed. Philadelpihia: Churchill Livingstone Elsevier, 2007; p.454-455.

4. Kawashima I, Fusigawa H, Obana M, Matsuoka Y. A case of AIDS complicated with liver tuberculosis. Journal of the Japanese Association for infectious diseases. 2000;74(11):984-988.

5. Aleen W. Problems and pitfalls in fine needle aspiration cytology of liver masses: part 1. Overview. Surabaya: $10^{\text {th }}$ National Conference of IAPI, 15-16 Sep- 
tember 2005; p.100-110.

6. Zachary GD, Kamal IG. Medical disease of the liver. In: Silverberg's principles and practice of surgical pathology and cytopathology, Steven G Silverberg, cs. Vol.2. $4^{\text {th }}$ ed. Philadelphia: Churchill Livingstone Elsevier, 2006; p.1508-1510.

7. Clive L. Primary macronodular hepatoc tuberculosis: US and CT appearances. Journal Abdominal Imaging. 1990;15 (1):307-309.

8. Laddawan V. Ultrasonography of focal hepatic lesions. In: Fine needle aspiration cytology of the liver. Diagnostic algorithms. A Southeast Asian prespective. Wee Aileen, Sampatanukul Pichet, editors. Bangkok: Year Book Publisher Co.Ltd., 2004; p.13-25.

9. Sudha KR. Color atlas of differential diagnosis in exfoliative and aspiration cytopathology. Philadelphia: Lippincott Williams and Wilkins, 1999; p.374.

10. Muhammad ZB. The liver and spleen. In: Koss LG. Koss' diagnostic cytology and its histopathologic bases. $5^{\text {th }}$ ed.
Philadelphia: Lippincott Williams and Wilkins, 2006; p.1398.

11. Desmet VJ and Juan R. Liver. Nonneoplastic diseases. Tumors and tumorlike conditions. In: Rosai and Ackerman's Surgical Pathology, Rosai Juan. $9^{\text {th }}$.ed.vol.1. Philadelphia: Mosby, 2004, p.962-963

12. Aileen W. Fine needle aspiration biopsy of the liver: Algorithmic approach and current isuues in the diagnosis of hepatocellular carcinoma. Surabaya: $10^{\text {th }}$ National Conference of IAPI 15-16 September 2005; p.35-61.

13. Crawford JM. Liver and biliary tract. In: Kumar, Abbas, Fausto. Robbins and Cotran Pathologic Basis of disease. $7^{\text {th }}$ ed. Philadelphia: Elsevier Saunders, 2005. p.922-927.

14. Aileen W, Pichet S. Case studies. In: Fine needle aspiration cytology of the liver. Diagnostic algorithms. A Southeast Asian prespective. Bangkok: Year Book Publisher Co.Ltd., 2004; p. 159-161. 